\title{
Effect of Implementation of Teaching Program on Pregnancy Outcome among Primipara Women Suffering from Pregnancy Induced Hypertension.
}

Faiza Mohamed Elsaid ${ }^{1}$, Manal Hassan Ahmed ${ }^{2}$, MostafaZein El- Abedin $^{3}$,Iman AbdelAzzizElkhayat ${ }^{4}$.

${ }^{1}$ Assisstant Lecturer of Maternal and Neonatal Health Nursing, Faculty of Nursing, Tanta University, Egypt.

${ }^{2}$ Prof. of Maternal and Neonatal Health Nursing, Faculty of Nursing, Tanta University, Egypt.

${ }^{3}$ Professor of Obstetrics and Gynecology, Faculty of Medicine, Tanta University, Egypt.

${ }^{4}$ Lecturersof Maternal and Neonatal Health Nursing, Faculty of Nursing, Tanta University, Egypt.

\begin{abstract}
:
Background: Pregnancy Induced Hypertension (PIH) is strongly associated with adverse outcomes to the mother, fetuses, as well as newborn. Health education intervention regarding risks and proper self-care measures will contribute to complications reduction and improve pregnancy outcome. The aim of this study: was to evaluate the effect of teaching program on pregnancy outcome among primipara women suffering from pregnancy induced hypertension. Subjects and Method: The study was conducted at antenatal unit in obstetric departments of Tanta University Hospital, El-Menshawy Hospital and $4 \mathrm{MCH}$ Centers in Tanta. Convenient samples of 60 pregnant women diagnosed with pregnancy induced hypertension were selected from the previously mentioned settingsaccording to the inclusive criteria. Three tools were used for data collection: Tool (I): A structure interview schedule that included three parts: (a) socio demographic characteristics, (b) Reproductive history, (c) History of present pregnancy. Tool (II): Structured women's Knowledge Interview Schedule that included three parts:Part a: women's knowledge regarding pregnancy induced hypertension, part b:women's knowledge regarding self-care management and part c:reportedwomen's self-care measures. Tool (III): Outcome Assessment Tool that included two parts: part I: Maternal outcome assessment sheet, part II: Neonatal outcome assessment sheet. Results: The resultsof the present study revealed improved women's level of knowledge as well as positive maternal and neonatal outcomes after implementation of health teachingprogram. Conclusion and Recommendation:The health education program had improved women's level of knowledge which consequently reflected positive effect on the maternal and neonatal outcomes. So, it is important toplan and develop antenatal health educational classes for all pregnant women. In addition, Provision of continuous refreshing courses, pre-service and in-service training programs should be provided for newly appointed nurses regarding PIH management at all levels of health care.
\end{abstract}

Keywords: Pregnancy Induced Hypertension, Maternal outcome, Neonatal outcome, and Health Education 


\section{Introduction}

Pregnancy is the time of physical and psychological preparation for birth and parenthood $^{(1)}$.Hypertensive disorder of pregnancy (HDP) are among the main public health issues worldwide and represents the most significant complications of pregnancy, as well as contributes significantly to maternal and perinatal morbidity and mortality ${ }^{(2)}$. It includes gestational hypertension $(\mathrm{GH})$ or pregnancy induced hypertension (PIH), pre-eclampsia(PE) and eclampsia ${ }^{(3)}$. Pregnancy induced hypertension is estimated to affect $7 \%$ to $10 \%$ of all pregnancies ${ }^{(4)}$. While the prevalence of HDP in Egypt is estimated to be $4.2 \%$ had $\mathrm{PIH}, 3.8 \%$ had PE, and $0.3 \%$ had eclampsia $^{(5)}$.

Gestational hypertension GH was adopted by NHBPEP 2000 to replace PIH which, is defined as the elevation of the blood pressure (BP) to $140 / 90 \mathrm{mmHg}$ or more with or without proteinuria or any systematic findings, which emerges for the first-time during pregnancy after 20 weeks of gestation and normally resolves by 12 weeks postpartum ${ }^{(6)}$. $\mathrm{PIH}$, especially $\mathrm{PE}$ is considered to be multifactorial disease. So, many theories have been developed about its pathogenesis, such as rejection phenomena, compromised placental perfusion, altered vascular reactivity, uterine muscle stretch, dietary factors, and genetic factors ${ }^{(7,8)}$.

Hypertension, collagen vascular disease, obesity, black race, insulin resistance, diabetes mellitus, gestational diabetes, increased serum testosterone concentration, nulliparity, severe anemia, renal disease, and thrombophilia are considered risk factors of PIH. A recent epidemiological study showed that black and some Hispanic woman had markedly increased risk of all HDP. Also, maternal age more than 30 years and body mass index (BMI) were found to be positively correlated to risk for PIH in Arab women $^{(7,9)}$.

Pregnancy induced hypertension PIHeffects on maternal, fetal, and neonatal organs ${ }^{(7)}$. Serious maternal effects include abruptio placenta, disseminated intravascular coagulation (DIC), eclampsia, acute renal failure, hemolysis, elevated liver enzymes and low platelet count (HELLP) syndrome and postpartum hemorrhage. While fetal effects include, low birth weight, hypoxia in the antenatal period, intrauterine death, early delivery which will produce preterm baby requires resuscitation, as well as neonatal effects that include small for gestational age 
(SGA) neonate, and low birth weight neonate $^{(7,10)}$.

Prediction of pregnancy induced hypertension PIH was based on the identification of the woman who predisposes to the occurrence of the disease. Early and regular antenatal checkup, adequate bed rest, daily low dose aspirin, calcium supplementation, antioxidants, vitamin $\mathrm{C}$ and $\mathrm{E}$, and wellbalanced diet all proposed to prevent the development of PE. But it is recommended that only low dose aspirin started in the first trimester in high risk women to reduce the risk of PE by up to 50\%. Also, calcium supplementation reduces the risk only in women who are deficient in dietary calcium $^{(11-13)}$.

Management of PIH depends on BP levels, gestational age, presence of symptoms and associated factors. Antihypertensive drugs are mainly used to prevent or treat severe hypertension, also to prolong pregnancy and prevent complications as eclampsia and maternal cerebral hemorrhage ${ }^{(7,11)}$. The definitive treatment of PE is termination of pregnancy so, the maternity nursesare directed toward continuationof pregnancy, without affecting the maternal prognosis until the fetus become mature enough to survive in the extra-uterine environment through regular antenatal visits with proper maternal and fetal monitoring which includes BP and weight monitoring, urinary protein analysis, abdominal examination, fetal assessment, laboratory studies, antihypertensive therapy and advice regarding rest, diet and warning signs ${ }^{(14,15)}$.

Thus,care of the women with PIH depends on the degree of severity of the process.Recent evidence suggests that high maternal mortality rate is as a result of inadequate knowledge, negative attitude and lack of preventive practice on the part of the pregnant women who have strong traditional beliefs ${ }^{(14-16)}$.Therefore, it was crucial to conduct the current study to determine the effect of implementation of teaching program on pregnancy outcome among primipara women suffering from PIH.

\section{Aim of the study}

The aim of this study was to evaluate the effect of teaching program on pregnancy outcome among primipara women suffering from pregnancy induced hypertension.

\section{Research hypothesis}

Maternal and neonatal outcomes are expected to be less or free from complications after implementation of the program provided to women with pregnancy induced hypertension. 


\section{Subjects and Method}

\section{Study design}

A quasi experimental research design was used in this study. Such design fits the nature of the study under investigations, in which the researcher tried to evaluate the effect of teaching program on pregnancy outcome among primipara women suffering from pregnancy induced hypertension between the studied women.

\section{Settings}

The study was conducted at antenatal unitsof obstetric departments at two hospital settings: Tanta University hospital, El-Menshawy hospital and 4 $\mathrm{MCH}$ centers affiliated to the different geographical health zones at Tantacitythese include:

1. Tanta Rabae at Kohafa.

2. Medical Center at Said.

3. Tanta Khames at El agizy.

4. Medical Center at Sager.

\section{Subjects}

A total convenient sample of 60 pregnant women diagnosed with pregnancy induced hypertension were selected from the previously mentioned settings.

The subjects of this study were selected according to the following inclusion criteria:

1. Diagnosed with pregnancy induced hypertension (PIH).
2. Gestational period from 28-32 weeks.

3. Primi-para women.

4. Free from other medical and obstetrical complications.

5. Willing to participate in the study.

\section{Tools of data collection}

Tools of data collection were developed by the researcher based on relevant literature and used to collect data about the study subjects as follows:-

\section{Tool I: Bio Socio-demographic,and reproductive and current} pregnancyhistory structured interview schedule: was used to collect basic data. It included three parts:

\section{Part a: Socio- demographic} dataincluded:age,level of education, marital status, place of residence, occupation, type of family, number of family members, family's income level, family history of Hypertension or (PIH), address and mobile or phone number.

\section{Part b: Reproductive history} included:number of pregnancy, problems with previous pregnancy, number of abortions, time and causes of abortion, last menstrual period (LMP), duration of current pregnancy (gestational weeks), and expected date of delivery. In addition to, antenatal booking as time of initial antenatal visit, number/follow- up of 
antenatal visits, and also, if they were attending antenatal care classes regarding $\mathrm{PIH}$.

Part c: Women's current pregnancy included: time of discovering the problem (gestational week at which PIH was diagnosed), type/degree of PIH, degree of blood pressure (from 140/90 to BL/P> 160/100), site of edema, presence of proteinuria by urinary dipstick test, presence of any symptoms as (headache, visual disturbances, blurring, flashing, nausea, vomiting, upper abdominal pain and brisk deep tendon reflex, compliance to treatment, and presence of any complications (fits and others).

Tool II: Women's Knowledge Assessment Tool:

This tool was developed by the researcher after reviewing of recent and related literature. It covered three sections which comprised a set of questions related to women's knowledge regarding pregnancy induced hypertension (PIH), self-care management of PIH, and reported women's self-care management related to PIH. It included three parts:

Part(1):This part included questions related to women's knowledge regarding pregnancyinduced hypertension: definition, classifications, etiology, signs and symptoms, high risk groups, effect of
PIH on pregnancy (maternal and fetal/neonatal complications), diagnostic testing, and therapeutic management.

Part (2):This part included questions related to women's knowledge regarding self-care management of PIH as; selfmonitoring of body weight, correct measurement of blood pressure, selfmonitoring of urinary dipstick test, selfmonitoring of edema, self-identification of danger signs and also self-monitoring of daily fetal movement.

Part (3): Assessment of reported women's self-care management regarding PIH: This tool was adapted from Hussian, Al-saffar (2016) ${ }^{(2)}$. It comprised 3 main items to assess women's reported self-caremanagement regarding $\mathrm{PIH}$ as; self-care management regarding feeding habits, self-care management regarding daily living activities and selfmonitoring of signs and symptoms of PIH.

Tool III: Outcome assessment tool: was used to assess maternal and neonatal outcome of the studied women and included two parts:-

Part I: Maternal outcome assessment: presence of maternal distress, mode of rupture of membranes- spontaneous or artificial, time of rupture of membranes (pre-mature or mature), type of delivery 
(normal or cesarean section), occurrence of complications during labor due to $\mathrm{PIH}$, such as abruption placenta, convulsions,preterm labor, disseminated intravascular coagulation (DIC) vaginal bleeding, pulmonary edema, acute renal failure, as well ashaemorrhage and postpartum haemorrhage, in addition to length of hospital stay.

Part II: Neonatal outcome assessment: included assessment of viability statusalive or stillborn, abnormal apgar score, need for resuscitation and oxygen administration, visible congenital malformation, birth weight measurement, gestation at delivery, and also neonatal complications such as; hypoglycemia or jaundice, signs of respiratory distress syndrome, admission of the neonate to intensive care unit, and length of stay at hospital.

\section{Methods}

The study was implemented according to the following steps:

\section{Administrative approval:}

- Official permission was obtained from responsible authority before conducting this study through official letters from faculty of Nursing Tanta University after clarifying the purpose of the study directed to hospital's directors of obstetrics departments at 6 settings ( Tanta University Hospital, El-Menshawy hospital and $4 \mathrm{MCH}$ centers at Tanta City) to obtain their approval and cooperation for carrying out the study.

\section{Tool development :}

- Tools (I, II, part 1 and 2, III) were developed by the researcher after reviewing recent literature. Then, they were tested for content and construct validity by three experts in the field of obstetric and gynecological nursing.

\section{Ethical considerations:women's}

- Informed oral consent was obtained from all the study participants who accepted to participate in the study after explaining the purpose of the study, confidentiality of information, benefits and right to withdraw from the study at any time if desired and that the nature of the study did not cause any harm and/or pain for the entire sample.

\section{Pilot study:}

After development of tools, a pilot study was carried out on $10 \%$ of the sample (6 women) who were excluded from the main study sample from the previously mentioned settings .This pilot study was conducted one month before data collection. 
The purposes of the pilot study were to:

- Ascertain the feasibility and applicability of the developed tools.

- Detect any problems peculiar to clarity of the statements that might interfere with the process of data collection.

\section{Results of the pilot study:}

The pilot study revealed that the sentences of the tools were clear and relevant. Few words and statements were rephrased and lor modified. Then, the tool was reconstructed and made ready for use.

\section{Tools reliability}

Validity test: Tools of data collection were distributed to a jury of 5 academic professors in Maternity and Gynecological Nursing Department to test its face and content validity. Accordingly, corrections and modifications were done.

The reliability of the translated Arabic tools was done by using Cronbach's Alpha which was 0.87 and 0.88 respectively.

\section{Actual study (field work)}

- The study was conducted in the period from 15/1/2019 to 30/9/2019at Tanta University hospital, El-Menshawy hospital and $4 \mathrm{MCH}$ centers in Tanta. The researcher was attended the sites of data collection 3days per week (on the morning shift) until the predetermined sample were collected. All cases presented at the time of data collection and had the inclusion criteria at each setting were included in the study.

\section{The study was carried out in four phases}

\section{a. Assessment and planning phase}

- The researcher introduced herself to the participants, obtainedtheir informed consent and the interview schedule was then conducted individually for each woman using Tool I to collect basic data about socio-demographic history, andreproductive history of current pregnancy.

- Knowledge of the studied women regarding $\mathrm{PIH}$, and self-care management were assessed using Tool II part 1, and 2 three times;before, immediately after and 2 weeks after the implementation of the educational program.

\section{b. Implementation phase}

- The educational sessions for the pregnant women composed of 3 main separate sessions given jointly with an educational booklet and carried-out in the previous mentioned settings. Each session ranged from 15-20 minutes.

- Booklet was developed by the researcher using simple Arabic language and illustrated pictures. It 
included the following: Information needed for pregnant women with $\mathrm{PIH}$ about PIH and women's self-care management.

- The researcher explained the purpose of the study to the pregnant women to obtain their acceptance to participate in the study.

- Before conducting the sessions, the researcher used (tool I part $1,2, \& 3$ ) to collected the socio-demographic data, and reproductive current pregnancy history of all studied women.(Tool II part 1,2, \&3) assessed women's knowledge regarding $\mathrm{PIH}$, self-care management of PIH and women's reported self-care management.

- The researcher distributed the booklet at the beginning of the first session to be used as a guide for self-learning, and raising women's self-efficiency about self-care measures regarding PIH.

- The first session: The researcher explained definition of $\mathrm{PIH}$, causes, classifications, signs and symptoms, high risk groups, expected complication of PIH and its effect on maternal and fetal/neonatal outcome, screening, and investigation used to diagnose PIH.
- The second session: The researcher clarified therapeutic management and its effectiveness in preventing complications. As well as selfidentification of danger signs as (headache, visual abnormalities, generalized edema, vomiting, and oliguria) ,dietary intake and food pattern, drugs, physical activity (exercise), and regular self monitoring of daily fetal movement .

- The Third session: The researcher emphasized on knowledge and redemonstration of women's self-care management regarding $\mathrm{PIH}$, such as daily self-monitoring of body weight, self-monitoring of urinary dipstick testing for screening for presence of proteinuria, self-monitoring of edema, and correct position for measurement of blood pressure.

\section{c. Evaluation phase}

- Tool II part 1, and 2 was used to assess women's knowledge before, immediately and two weeks after the program.

- Tool II part 3 was used to assess women's reported self-care management before, immediately, and two weeks after the program.

- Tool III was used to assess maternal 
outcome and neonatal outcome before, immediately, and two weeks after the program.

\section{- Statistical analysis:}

- Statistical analysis of the data was carried out and the collected data was organized, categorized, computerized tabulated and analyzed by the statistical package for social sciences (Version 20.0. Armonk, NY: IBM Corp).

\section{Results}

Table (1): Shows the socio-demographic characteristics of the studied pregnant women. It was observed that the mean age of the study subjects were $25.13 \pm 3.45$ years, more than two-third $(71.7 \%)$ were born in rural areas, and more than the half $(58.3 \%)$ of the study subjects had secondary equivalent education. Considering occupation, slightly more than three quarters of the study subjects (78.3.0\%) were housewife. Furthermore, less than the half $(41.7 \%)$ of the study subjects had barely enough income, and more than one-third (33.3\%) hadn't enough income per month.Moreover, more than two-third $(66.7 \%)$ of them had family history of hypertension.

Table (2): Describes distribution of reproductive history of the studied pregnant women. It was found that the majority of the study subjects $(83.3 \%)$ had no history of abortion and also was primigravida. As regard the number of weeks of gestation, the mean of gestational age of the study subjects were $29.77 \pm 0.89$. Concerning the time of initial antenatal visit it was illustrated that more than half of the study subjects $(53.3 \%)$ were started late with a mean\& $\mathrm{SD}=24.37 \pm 2.6$. The mean of antenatal visit of current pregnancy was $4.37 \pm 0.99$ visits. In relation to attendance of antenatal classes about $\mathrm{PIH}$, no woman of the study subject had attended to antenatal classes about PIH. As well as no woman of the study subject had $\mathrm{PIH}$ in the previous pregnancy.

Figure (1):Clarifies the total score level of pregnant women's knowledge regarding Pregnancy induced hypertension. It was found that more than half $(58.3 \%)$ of the studied women their total score level of knowledge about PIH was poor before implementing the educational session, while the majority of the sample $(88.4 \%$ and $75.0 \%$ respectively) had good level of knowledge immediately and 2 weeks post -program, the difference was statistically significant $\left(X^{2} 88.295, \mathrm{P}<0.001\right)$.

Figure (2): Clarifies the total score level of the studied women's knowledge regarding practices of PIH. It was found that the total score level of women's 
knowledge regarding practices of PIH was poor $(68.4 \%)$ before implementing the educational session, while the majority of the sample $(91.7 \%$ and $88.3 \%$ respectively) had good total score level of knowledge immediately and 2 weeks postprogram, the difference was statistically significant $\left(\mathrm{X}^{2} 78.313, \mathrm{P}<0.001\right)$.

Figure (3):Clarifies the total score level of the studied pregnant women's reported self-care management. It was found that more than two-third of the women $(70 \%)$ had inadequate self-care management regarding self-care management before implementing the educational session, while the majority of them $(88.3 \% \%$ and $85 \%$ respectively) had adequate self-care management immediately and 2 weeks post -program. These findings was statistically $\quad$ significant $\left(X^{2} \quad 37.136\right.$, $\mathrm{P}<0.001)$.

Table (3): Shows percent distribution of the studied women's pregnancy outcomes after delivery. It was observed that the majority of the studied women (96.6\%) delivered cesarean section. Regarding occurrence of complications, it was clear that the majority (95\%) had no complications, and only $5 \%$ of the studied women had complications (antepartum hemorrhage, postpartum haemorrhage, and coagulation disorders). It was also found that none of the women were admitted to the intensive care unit (ICU).

Table (4): Shows assessment of the neonate outcome among the studied women after delivery, according to the viability status of fetus, it was observed that the majority of the fetuses $(98.3 \%)$ were live born.Considering the gestational age at delivery, it was found that slightly less than three-quarter $(73.3 \%)$ were born full term, while one quarter were born preterm, and only $1.7 \%$ born preterm. The mean birth apgar score at first minute and at fifth minute was $(6.89 \pm 0.92 \mathrm{P}$ and 7.19 \pm 1.23 respectively). It was also clear that three-quarter $(75 \%)$ of the neonates were normal birth weight, and the majority (91.7\%) didn't admit to the intensive care unit. 
Table (1): Percent distribution of socio-demographic characteristics of the studied Pregnant women $(\mathbf{n}=60)$

\begin{tabular}{|c|c|c|}
\hline \multirow[t]{2}{*}{ Socio-demographic characteristics } & \multicolumn{2}{|c|}{$\begin{array}{l}\text { The studied pregnant women } \\
(\mathrm{n}=60)\end{array}$} \\
\hline & No & $\%$ \\
\hline \multirow{5}{*}{$\begin{array}{l}\text { Age }(\text { years }) \\
<25 \\
25-<30 \\
30 \text { or more } \\
\text { Mean } \pm \text { SD }\end{array}$} & & \\
\hline & 25 & 41.7 \\
\hline & 24 & 40.0 \\
\hline & 11 & 18.3 \\
\hline & \multicolumn{2}{|c|}{$25.13 \pm 3.45$} \\
\hline $\begin{array}{l}\text { Marital status } \\
\text { Married }\end{array}$ & 60 & 100.0 \\
\hline $\begin{array}{l}\text { Residence } \\
\text { Urban } \\
\text { Rural }\end{array}$ & $\begin{array}{l}17 \\
43\end{array}$ & $\begin{array}{l}28.3 \\
71.7\end{array}$ \\
\hline $\begin{array}{l}\text { Level of education } \\
\text { Illiterate } \\
\text { Elementary or preparatory } \\
\text { Secondary or equivalent } \\
\text { University or above }\end{array}$ & $\begin{array}{l}10 \\
8 \\
35 \\
7\end{array}$ & $\begin{array}{l}16.7 \\
13.3 \\
58.3 \\
11.7\end{array}$ \\
\hline $\begin{array}{l}\text { Occupation } \\
\text { Housewife } \\
\text { Work } \\
\text { Type of work } \\
\text { Worker } \\
\text { Employee } \\
\text { Teacher }\end{array}$ & $\begin{array}{l}47 \\
13 \\
(\mathrm{~N}=13) \\
4 \\
7 \\
2\end{array}$ & $\begin{array}{l}78.3 \\
21.7 \\
\\
\\
30.8 \\
53.8 \\
15.4\end{array}$ \\
\hline $\begin{array}{l}\text { Type of family } \\
\text { Nuclear family } \\
\text { Extended family }\end{array}$ & $\begin{array}{l}37 \\
23\end{array}$ & $\begin{array}{l}61.7 \\
38.3\end{array}$ \\
\hline $\begin{array}{l}\text { Number of family members } \\
\text { Less than } 3 \\
3-5 \\
6 \text { or more }\end{array}$ & $\begin{array}{l}47 \\
11 \\
2\end{array}$ & $\begin{array}{l}78.4 \\
18.3 \\
3.3\end{array}$ \\
\hline $\begin{array}{l}\text { Family income per Month: } \\
\text { Enough } \\
\text { Barely enough } \\
\text { Not enough }\end{array}$ & $\begin{array}{l}15 \\
25 \\
20\end{array}$ & $\begin{array}{l}25.0 \\
41.7 \\
33.3\end{array}$ \\
\hline $\begin{array}{l}\text { Family history of hypertension } \\
\text { Yes } \\
\text { No }\end{array}$ & $\begin{array}{l}40 \\
20\end{array}$ & $\begin{array}{l}66.7 \\
33.3\end{array}$ \\
\hline $\begin{array}{l}\text { Degree of proximity }(\mathbf{n}=\mathbf{2 0}) \\
\text { First degree } \\
\text { second degree }\end{array}$ & $\begin{array}{l}17 \\
3\end{array}$ & $\begin{array}{l}85.0 \\
15.0\end{array}$ \\
\hline
\end{tabular}


Table (2): Percent distribution of reproductive history of the studied pregnant women .

\begin{tabular}{|c|c|c|}
\hline \multirow{2}{*}{ Reproductive history } & \multicolumn{2}{|c|}{$(n=60)$} \\
\hline & $\mathbf{N}$ & $\%$ \\
\hline $\begin{array}{l}\text { Number of gravid } \\
\text { Primigravida } \\
\text { Two } \\
\text { Three }\end{array}$ & $\begin{array}{l}50 \\
8 \\
2\end{array}$ & $\begin{array}{l}83.3 \\
13.3 \\
3.4 \\
\end{array}$ \\
\hline $\begin{array}{l}\text { History of PIH in previous pregnancy } \\
\text { Yes } \\
\text { No }\end{array}$ & $\begin{array}{l}0 \\
60\end{array}$ & $\begin{array}{l}0.0 \\
100\end{array}$ \\
\hline $\begin{array}{l}\text { Number of abortion } \\
\text { None } \\
\text { One } \\
\text { Two }\end{array}$ & $\begin{array}{l}50 \\
8 \\
2\end{array}$ & $\begin{array}{l}83.3 \\
13.3 \\
3.4\end{array}$ \\
\hline $\begin{array}{l}\text { Duration of current pregnancy(weeks of ge } \\
\text { Mean } \pm S D\end{array}$ & \multicolumn{2}{|c|}{$29.77 \pm 0.89$} \\
\hline \multirow[t]{2}{*}{$\begin{array}{l}\text { Time of first antenatal care visit } \\
\text { Early (In the } 1^{\text {st }} \text { trimester) } \\
\text { Late( In the } 2^{\text {nd }} \text { trimester) } \\
\text { Mean } \pm \text { SD }\end{array}$} & $\begin{array}{l}28 \\
32\end{array}$ & $\begin{array}{l}46.7 \\
53.3\end{array}$ \\
\hline & \multicolumn{2}{|c|}{$24.37 \pm 2.6$} \\
\hline $\begin{array}{l}\text { Number of antenatal visits of current preg } \\
\text { Mean } \pm \text { SD }\end{array}$ & \multicolumn{2}{|c|}{$4.37 \pm 0.99$} \\
\hline $\begin{array}{l}\text { Attendance of antenatal classes about PIH } \\
\text { Yes } \\
\text { No }\end{array}$ & $\begin{array}{l}0 \\
60\end{array}$ & $\begin{array}{l}0.0 \\
100\end{array}$ \\
\hline
\end{tabular}




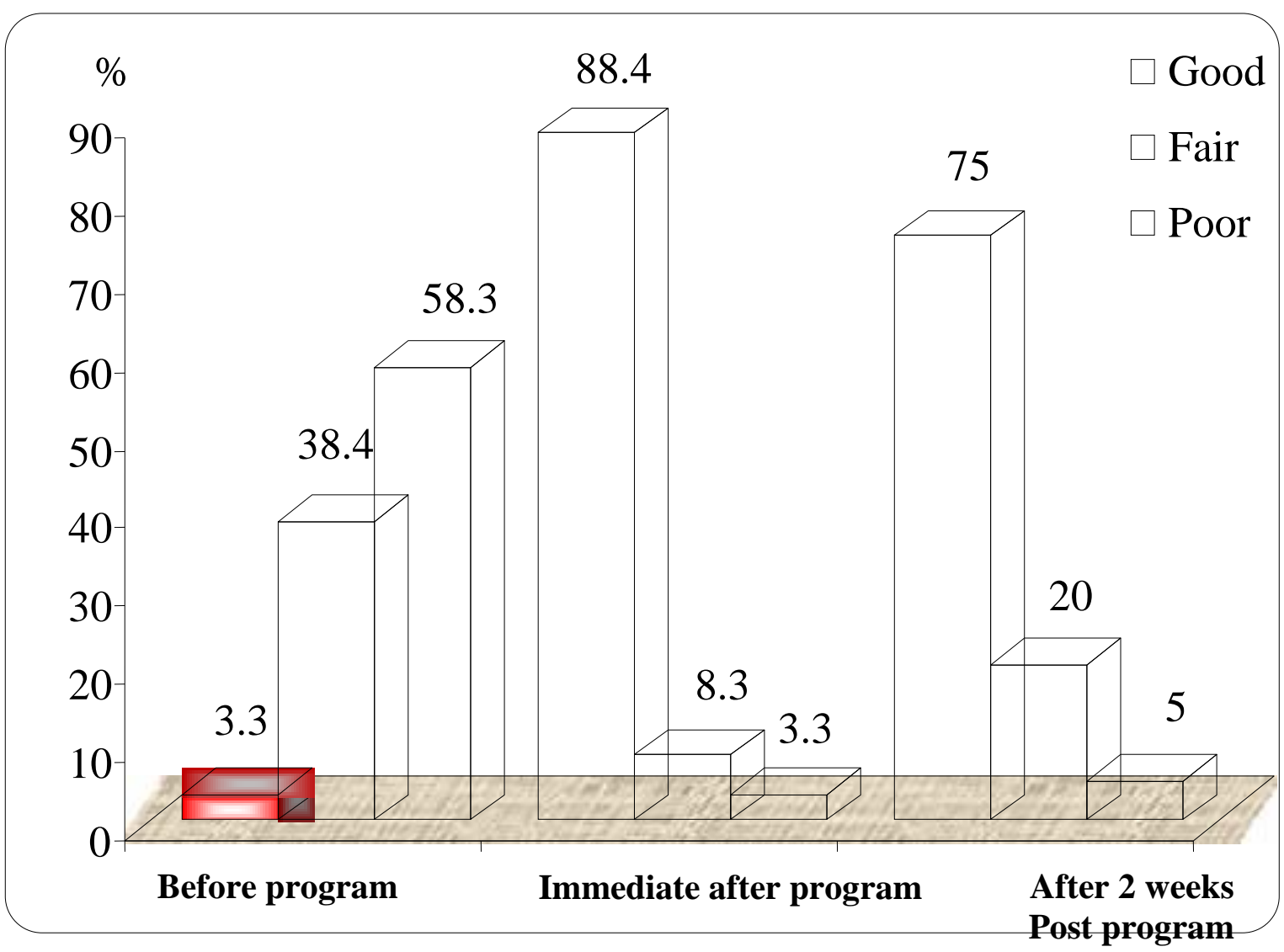

Figure (1): Total score level of women's knowledge regarding Pregnancy induced hypertension, before, immediate and after implementation of the educational program. 


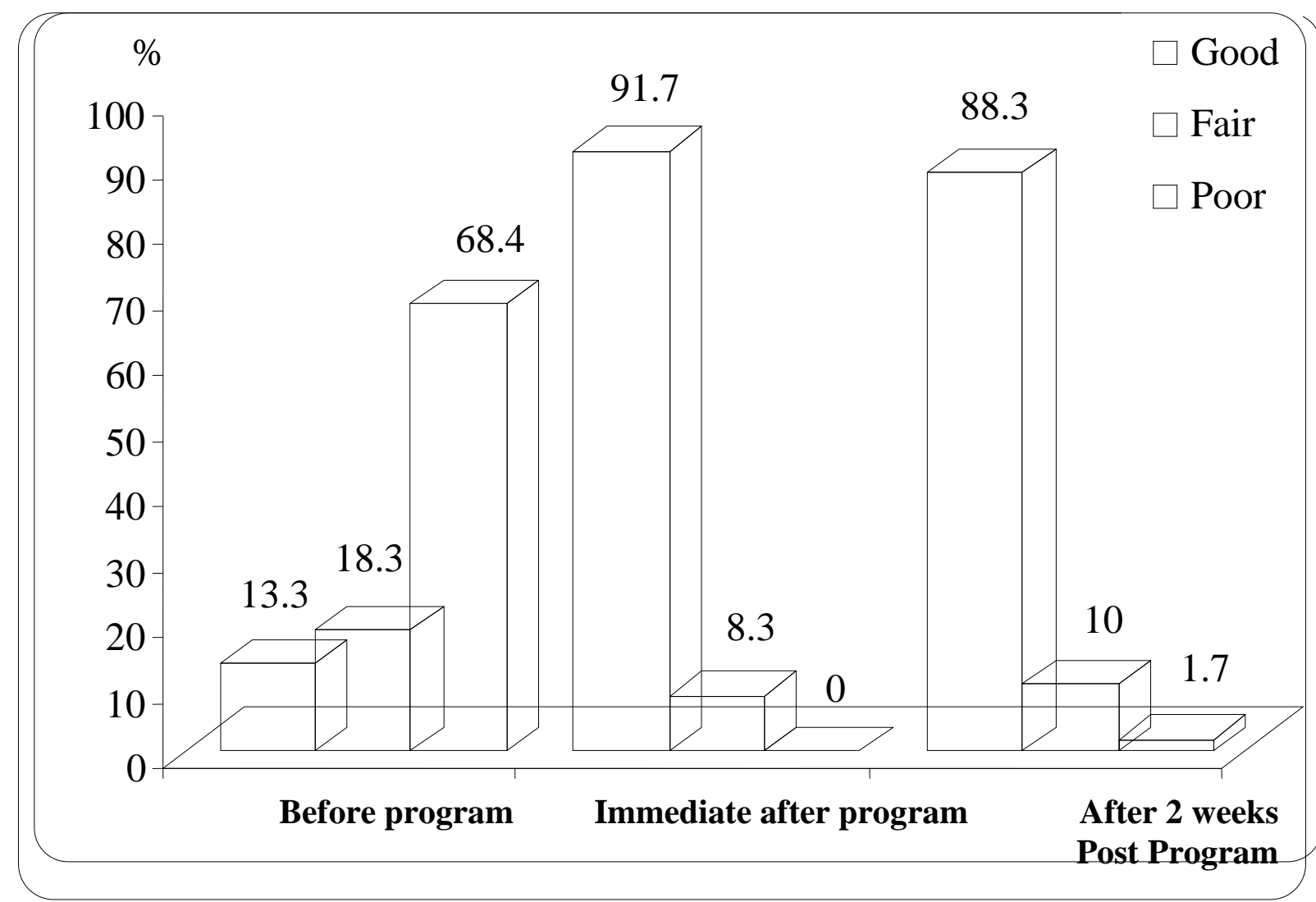

Figure (2): Total score level of the studied women's knowledge regarding practices of PIH before, immediate and 2 weeks after implementation of the educational program.

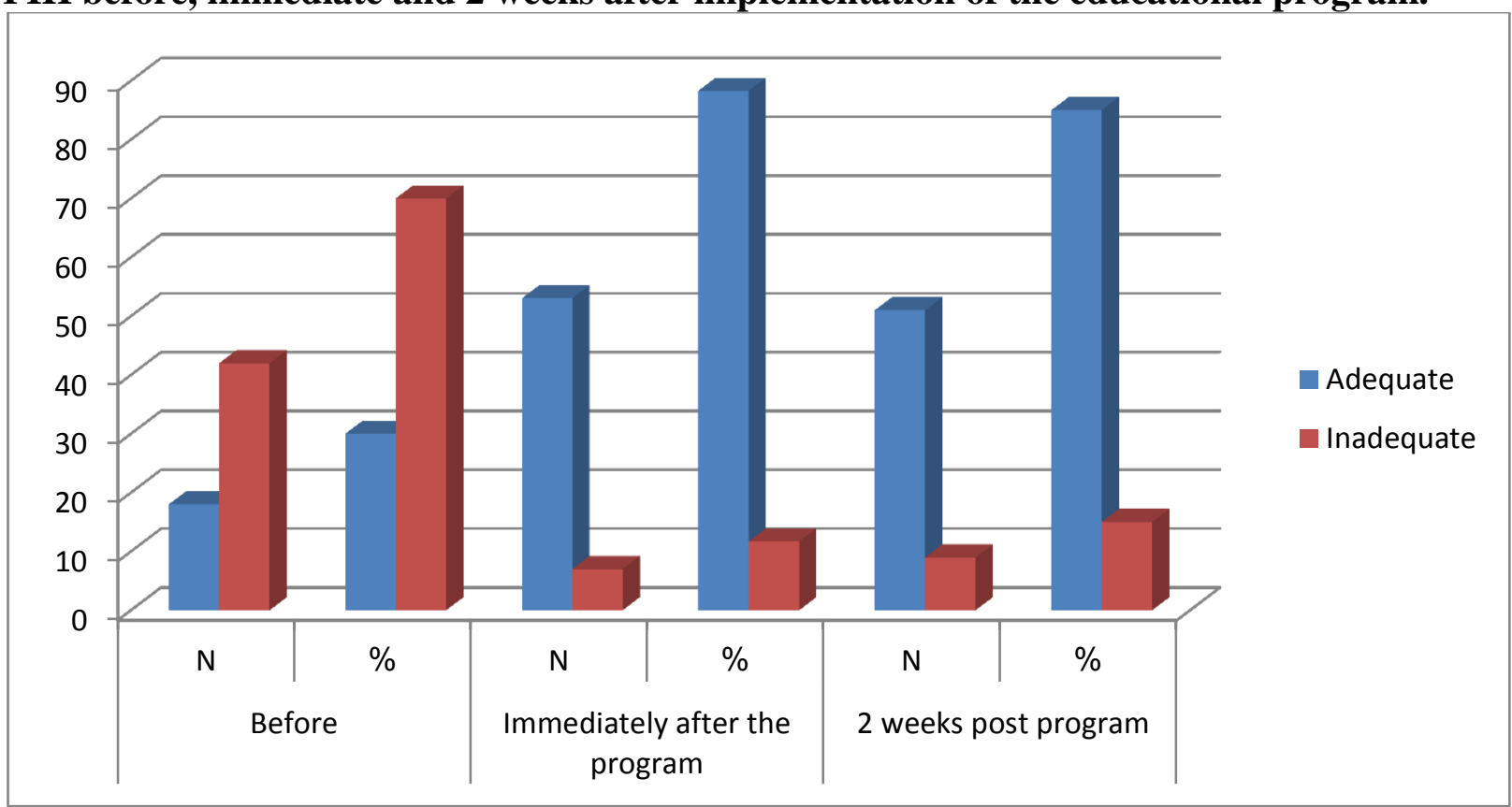

Figure (3): Total score level of the studied women's reported regarding self-care management of PIH before, immediate and 2 weeks after implementation of the educational program. 
Table (3): Assessment of the studied women's pregnancy outcome (maternal outcome)

\begin{tabular}{|c|c|c|}
\hline \multirow{2}{*}{ Pregnancy outcome } & \multicolumn{2}{|c|}{$(n=60)$} \\
\hline & No & $\%$ \\
\hline $\begin{array}{l}\text { Type of delivery } \\
\text { Normal } \\
\text { Cesarean }\end{array}$ & $\begin{array}{l}2 \\
58 \\
\end{array}$ & $\begin{array}{l}3.33 \\
96.67 \\
\end{array}$ \\
\hline $\begin{array}{l}\text { Occurrence of a raised complications regarding PIH\# } \\
\text { Coagulation disorders(thrombocytopenia) } \\
\text { Antepartum haemorrage } \\
\text { Postpartum haemorrhage } \\
\text { None }\end{array}$ & $\begin{array}{l}2 \\
1 \\
1 \\
57\end{array}$ & $\begin{array}{l}3.33 \\
1.66 \\
1.66 \\
95\end{array}$ \\
\hline $\begin{array}{l}\text { Maternal distress } \\
\text { Present } \\
\text { Absent }\end{array}$ & $\begin{array}{l}0 \\
60 \\
\end{array}$ & $\begin{array}{l}0 \\
100 \\
\end{array}$ \\
\hline $\begin{array}{l}\text { Labor complications regarding PIH } \\
\text { Present } \\
\text { Absent }\end{array}$ & $\begin{array}{l}0 \\
60 \\
\end{array}$ & $\begin{array}{l}0 \\
100 \\
\end{array}$ \\
\hline $\begin{array}{l}\text { Admission to intensive care unit (ICU) } \\
\text { Yes } \\
\text { No } \\
\end{array}$ & $\begin{array}{l}0 \\
60 \\
\end{array}$ & $\begin{array}{l}0 \\
100 \\
\end{array}$ \\
\hline $\begin{array}{l}\text { Length of hospital stay } \\
\text { Hours } \\
\text { Day } \\
\text { More than one day } \\
\end{array}$ & $\begin{array}{l}2 \\
54 \\
4\end{array}$ & $\begin{array}{l}3.3 \\
90 \\
6.7 \\
\end{array}$ \\
\hline $\begin{array}{l}\text { Crisis of severe stress or depression } \\
\text { Yes } \\
\text { No } \\
\end{array}$ & $\begin{array}{l}4 \\
56 \\
\end{array}$ & $\begin{array}{l}6.7 \\
93.3 \\
\end{array}$ \\
\hline $\begin{array}{l}\text { Continuous need for analgesics } \\
\text { Yes } \\
\text { No }\end{array}$ & $\begin{array}{l}2 \\
58\end{array}$ & $\begin{array}{l}3.3 \\
96.7\end{array}$ \\
\hline $\begin{array}{l}\text { Problems with sleeping } \\
\text { Yes } \\
\text { No }\end{array}$ & $\begin{array}{l}4 \\
56 \\
\end{array}$ & $\begin{array}{l}6.7 \\
93.3 \\
\end{array}$ \\
\hline $\begin{array}{l}\text { Complain from diarrhea, vomiting or epigastric pain after } \\
\text { delivery } \\
\text { Yes } \\
\text { No }\end{array}$ & $\begin{array}{l}0 \\
60\end{array}$ & $\begin{array}{l}0.0 \\
100.0\end{array}$ \\
\hline $\begin{array}{l}\text { Occurrence of convulsions after delivery } \\
\text { Yes } \\
\text { No }\end{array}$ & $\begin{array}{c}0 \\
60\end{array}$ & $\begin{array}{r}0.0 \\
100\end{array}$ \\
\hline
\end{tabular}

\# More than one item 
Table (4): Assessment of the studied women's pregnancy outcomes(neonate outcome)

\begin{tabular}{|c|c|c|}
\hline \multirow{2}{*}{ Neonatal outcomes. } & \multicolumn{2}{|c|}{$(n=60)$} \\
\hline & No & $\%$ \\
\hline $\begin{array}{l}\text { Viability status of the fetus } \\
\text { Live born } \\
\text { Neonatal death }\end{array}$ & $\begin{array}{l}59 \\
1\end{array}$ & $\begin{array}{l}98.3 \\
1.7\end{array}$ \\
\hline $\begin{array}{l}\text { Gestational Age at delivery (wks) } \\
\text { Preterm } 34-36 \\
\text { Full term }>=37\end{array}$ & $\begin{array}{l}16 \\
44\end{array}$ & $\begin{array}{l}26.7 \\
73.3\end{array}$ \\
\hline $\begin{array}{l}<7 \\
\text { Apgar score at } 1 \text { min. }(\mathbf{n}=\mathbf{5 8}) \\
>=7 \\
\text { Mean } \pm \text { SD }\end{array}$ & \multicolumn{2}{|c|}{$6.89 \pm 0.92$} \\
\hline $\begin{array}{l}\text { Apgar score at } 5 \text { min. }(\mathbf{n}=\mathbf{5 8}) \\
<7 \\
>=7 \\
\text { Mean } \pm \text { SD }\end{array}$ & $\begin{array}{l}17 \\
41 \\
7 .\end{array}$ & $\begin{array}{l}29.3 \\
70.7\end{array}$ \\
\hline $\begin{array}{l}\text { Weight } \\
\text { Low birth weight }<2.5 \mathrm{~kg} \\
\text { Normal birth weight } 2.5 \mathrm{~kg} \text { or more } \\
\end{array}$ & $\begin{array}{l}15 \\
45 \\
\end{array}$ & $\begin{array}{l}25.0 \\
75.0 \\
\end{array}$ \\
\hline $\begin{array}{l}\text { Height } \\
41-49 \mathrm{~cm} \\
50-53 \mathrm{~cm}\end{array}$ & $\begin{array}{c}54 \\
6 \\
\end{array}$ & $\begin{array}{l}90.0 \\
10.0 \\
\end{array}$ \\
\hline $\begin{array}{l}\text { Intra-uterine fetal growth retardation } \\
\text { Yes } \\
\text { No }\end{array}$ & $\begin{array}{c}0 \\
60\end{array}$ & $\begin{array}{l}0.00 \\
100\end{array}$ \\
\hline $\begin{array}{l}\text { Needs of neonate for oxygen administration/ } \\
\text { resuscitations } \\
\text { Yes } \\
\text { No } \\
\end{array}$ & $\begin{array}{c}6 \\
54\end{array}$ & $\begin{array}{l}10 \\
90\end{array}$ \\
\hline $\begin{array}{l}\text { Presence of any congenital anomalies } \\
\text { Yes } \\
\text { No }\end{array}$ & $\begin{array}{c}0 \\
60\end{array}$ & $\begin{array}{l}0.00 \\
100\end{array}$ \\
\hline $\begin{array}{l}\text { Occurrence of respiratory distress syndrome } \\
\text { Yes } \\
\text { No }\end{array}$ & $\begin{array}{c}4 \\
56\end{array}$ & $\begin{array}{c}6.7 \\
93.3\end{array}$ \\
\hline $\begin{array}{l}\text { Presence o meconium in the amniotic fluid(fetal } \\
\text { distress) } \\
\text { Yes } \\
\text { No } \\
\end{array}$ & $\begin{array}{c}0 \\
60\end{array}$ & $\begin{array}{l}0.00 \\
100\end{array}$ \\
\hline $\begin{array}{l}\text { Admission of neonate to intensive care unit } \\
\text { Yes } \\
\text { No }\end{array}$ & $\begin{array}{c}5 \\
55\end{array}$ & $\begin{array}{c}8.3 \\
91.7\end{array}$ \\
\hline $\begin{array}{l}\text { Length of stay at intensive care unit }(\mathbf{n}=5) \\
\text { Hours } \\
\text { Days } \\
\text { Weeks or more }\end{array}$ & $\begin{array}{l}2 \\
2 \\
1\end{array}$ & $\begin{array}{r}40.0 \\
40.0 \\
20.00\end{array}$ \\
\hline $\begin{array}{l}\text { Occurrence of any problems after delivery } \\
\text { Hypoglycemia } \\
\text { Jaundice in the first } 24 \text { hours }\end{array}$ & $\begin{array}{l}2 \\
1\end{array}$ & $\begin{array}{l}3.3 \\
1.7\end{array}$ \\
\hline
\end{tabular}




\section{Discussion}

Pregnancy induced hypertension $(\mathrm{PIH})$ is defined as hypertension that develops direct from the gravid state includes $\mathrm{GH}$, pre-eclampsia, and eclampsia. About $10 \%$ of pregnancy is complicated with HDP. HDP is a multi-organ, heterogeneous disorder of pregnancy and their incidence is increasing.Inaddition PIH lead to significant maternal, fetal, neonatal mortality and morbidity (17). Effective management of $\mathrm{PIH}$ with health educational intervention can significantly help women to acquire new knowledge, skills and actions to cope with the practical aspects of self-care measures regarding $\mathrm{PIH}{ }^{(18)}$. Therefore, the current study was conducted to evaluate the effect of implementation of health education program on pregnancy outcome among primipara women suffering from pregnancy induced hypertension.

\section{Concerningsocio-demographic}

characteristics of the studied women, the finding of the present study revealed that $\mathrm{PIH}$ cases their mean age were 25.13 +3.45. In addition, more than half of women were from rural areas, had secondary/diploma education, and were housewives. Also, less than half of studied women their family income per month from their point of view was barely enough and only one-quarter their income were enough. As well as socioeconomic factors such as, low income, poor education, residences in low income areas are strong indicators of the development of hypertension. These findings are supported by, Shahid et al. (2012) ${ }^{(19)}$, Parmer et al. (2012) ${ }^{(20)}$, and Martins et al.(2012) ${ }^{(21)}$, they showed that incidence of PIH was higher among women with low socioeconomic status, low educational level and unemployed women.

Concerning the reproductive history of the studied women, the findings of the current study reported that more than half of the studied women start antenatal care visit later after 20 weeks gestation and the majority of them reported that they had their initial antenatal visit after 20 weeks gestation to take tetanus vaccine. The mean of antenatal visits number of current pregnancy were $4.37+0.99$. These findings are in agreement with E-Moselhy et al. (2011) (22), who recommended that antenatal care for pregnant women should be improved and mothers in different areas in Egypt must be understand the epidemiology of $\mathrm{PIH}$ as a primary prevention, consequently careful antenatal care especially for women at risk of preeclampsia is recommended. On the 
other hand,El Shair et al. (2012) ${ }^{(23)}$,study revealed that most of pregnant women were registered later to the antenatal care.

Furthermore, it is disappointing to say that all of the studied women did not attend any health education classes during pregnancy related to $\mathrm{PIH}$. The results of the present study could be reasonable proof of drawbacks of health education topics as $\mathrm{PIH}$ during antenatal care provided to women during antenatal visits. Needless to say that providing essential health education to pregnant women through antenatal care has been advocated as effective tools to reduce maternal and prenatal morbidity as well as mortality.

As regards total women's knowledge level regarding PIH before and after implementation of the health education sessions, the present study revealed that accordingly, before health education sessions more than half of the studied women had poor level of knowledge regarding PIH. These results are supported by Maputle et al. (2015) ${ }^{(24)}$, who assess knowledge towards PIH among pregnant women and revealed that the majority of pregnant women had deficit knowledge about PIH. Moreover, Salim et al. (2017) ${ }^{(25)}$, had assessed knowledge of gestational hypertension among primigravida women and pointed out that about three-quarter of the study sample had poor level of knowledge regarding gestational hypertension.

\section{After implementation of health education} sessions, about three-quarter of women accomplished good level of knowledge regarding $\mathrm{PIH}$. While there is slightly decline in knowledge level after 2 weeks follow up compared to the immediate post test. This may be due to, studied women might forget some knowledge or may be due to fear/stress from delivery which is expected. Nonetheless, the levels were still significantly higher than pre-program levels. These results are supported by Joseph (2013) ${ }^{(26)}$, who mentioned that the majority of antenatal mothers accomplished maximum knowledge score after antenatal care package which was effective in improving their knowledge about PIH.

The findings of the current study revealed that the majority of the studied women accomplished good level of knowledge regarding self-care management. These results are supported byJayasutha et al. (2013) ${ }^{(27)}$, who assessed the impact of PIH and patient counseling on pregnancy outcome. They stated that an improvement in patient's knowledge increase their understanding about the disease, therapies. Thus enhanced compliance and improve 
pregnancy outcome. Many studies also recommended continuous educational programs as well as scientific researches to enhance pregnancy outcome.

According to the studied women's reported self-care management regarding

$\boldsymbol{P I H}$, the findings of the present study revealed that the majority of the studied women had inadequate level of self-care measures before health education sessions, these results are dissimilar with Hussian et al. (2016) ${ }^{(2)}$, who assessed self-care management of PIH for pregnant women attending primary health care centers. They mentioned that women's level of self-care management of PIH was adequate and noone among the studied items are formed low assessment. The possible explanations of the finding of the present study involve that study sample were primipara women and more than half of them started antenatal care visits later after 20 weeks gestation as well as no one of them attending antenatal classes related to PIH.

As regards to maternal outcomes, the results of the current study revealed that the majority of the studied women had no complications. These results are supported byKolluru et al. (2016) ${ }^{(28)}$, who observed that maternal complications of hypertensive pregnant women were less in booked women than un-booked and
HELLP syndrome was the commonest maternal complication followed by acute renal failure. Another study done by, Parmar et al.(2017) ${ }^{(29)}$, stated that highest incidence of eclampsia followed by antepartum hemorrhage and disseminated intravascular coagulation respectively among the hypertensive pregnant women who had lack of awareness regarding antenatal care. Additionally,Kilembe et al. (2004) ${ }^{(30)}$, they confirmed that only half of studied women are booked for antenatal care, so that maternal complications included highest rate of eclampsia, followed by severe preeclampsia, disseminated intravascular coagulation (DIC), acute renal failure (ARF), pulmonary oedema as well as maternal death.

Moreover the present study concluded that the majority of fetuses were survived without any complications, and about three-quarter newborns were delivered with normal birth weight $2.5 \mathrm{~kg}$ or more. These results are consistent with Abdelati et al. (2016) ${ }^{(31)}$, who presented that neonatal outcomes were improved among mothers group received nursing care after implementation of educational program for them as regards newborn measurements, and prenatal and also postnatal complications. At the same line 
Hassan et al. (2015) ${ }^{(32)}$, reported that the majority of fetus survived and respiratory distress syndrome was the most common cause of admission to intensive care units as well as increase percentage of fetus with low birth weight. This because that about half of mothers revealed irregular ANC less than 4 visits.

Accordingly, empowering women with knowledge regarding $\mathrm{PIH}$ through health education program enables them to seek care, follow medical procedures, and participate in health education program. Knowledge and awareness about PIH and its self-care management are translated to improve their self-care measures and increase their commitment with the care regimen, which ultimately contributed to complications reduction. So, the study findings have proved that health education program is necessary step for better management of PIH to improve pregnancy outcomes for the women and her offspring.

\section{Conclusion}

Based on the findings of the present study, it can be concluded thatthe studied pregnant women revealed improvement of their level of knowledge as well as their self -care management regarding PIH after implementation of health educational program which inturn reflect positive effect on the maternal and neonatal outcomes.

\section{Recommendations}

This study recommended Planning and development of antenatal health educational classes for all pregnant women to increase their awareness about importance of early antenatal care, as well as proper screening for early diagnosis and effective management of $\mathrm{PIH}$ to improve their pregnancy outcome.

\section{References:}

1. ZuoTC, Teng SP, Keng SL, Jummaat F.Knowledge of preeclampsia among antenatal women in a tertiary referral teaching hospital. The Malaysian Journal of Nursing.2016; 7(2):8-13.

2. Hussian MH, Al-saffar F. Self-care management of pregnancy induced hypertension for Pregnant women attending primary health care centers at Kirkuk City.Kufa Journal for Health Sciences. 2016;2(6):1-10.

\section{Lowdermilk DL, Perry SE, Cashion} K, Alden KR. Maternity and Women's Health Care. $11^{\text {th }}$ ed. USA: Elsevier Inc.;2016. 653-667.

\section{Jena M, Mishra S, Jena S, Pradhan S,} Das S, Jena J, et al. Pregnancy induced hypertension and preeclampsia: Pathophysiology and recent 
management trends: A review. International Journal of Pharmaceutical Research and Allied Sciences. 2016; 5(3):326-334.

5. El-Deeb SIH, El-Bakry MM, Nouh A, Mohamed SM.Prevalence of pregnancy induced hypertension, Zagazig University Hospital.Unpublished Master Thesis, Faculty of Medicine, Zagazig University,2015.

6. GabalMS, Abousaif HA, Salah-Eldin W, Abdelaziz AM. Frequency of hypertension associated with pregnancy among the pregnant women attending maternal and child care centers in Belbeis City. The Egyptian Journal of Community Medicine. 2017;35 (3):83-91.

\section{Kintiraki E, Papakatsika S, Kotronis} G, Dimitrios G, Kotsis V. Pregnancy Induced Hypertension.Springer Link Journal.2015; 14(2):211.

8. El-Moselhy EA, Klalifa HO, Amer SM, Abd El-Aal HM. Risk factors and impacts of preeclampsia: An epidemiological study among pregnant mothers in Cairo, Egypt. Journal of American Science. 2011;7(5):311-323.

9. Jones L, Takramah W, Axame WK, Owusu R, Parbey PA, Tarkangg E, et al. Risk factors associated with pregnancy induced hypertension in the
Hohoe Municipality of Ghana,. Journal of Preventive Medicine and Healthcare. 2017;1(3):1011.

10. Khosravi S, Dabiran S, Lotfi M, Asnavandy M. Study of the prevalence of hypertension and complications of hypertensive disorders in pregnancy. Open Journal of Preventive Medicine. 2014; 4(1):860-867.

11. Marshall JE, Raynor MD, Nolte AGW. Myles textbook for midwives. $3^{\text {rd }}$ ed..South Africa: Elsevier Ltd.;2016. 197-212.

12. Jacob A, Krishnaveni TM.A comprehensive textbook of midwifery and gynecological nursing. $4^{\text {th }}$ ed..London, Published by Elsevier com., 2012. 337-51.

13. Townsend R, Brien PO, Khalil A. Current best practice in the management of hypertensive disorders in pregnancy, integrated Blood Pressure Control, biomedical and life.Sciences Journal. 2016;9(1):79-94.

14. Elizabeth M. Midwifery Nurses. $2^{\text {nd }}$ ed. New Delhi, India: Elsevier Ltd com., 2013. 206-21.

15. Luesley DM, Baker PN. Obstetrics and gynecology. $2^{\text {nd }}$ ed. London: Health Sciences Publisher, 2012.180-6. 


\section{Fadare R, Akpor O, Oziegbe $\mathbf{O}$.} Knowledge and attitude of pregnant women towards management of pregnancy induced hypertension in Southwest Nigeria. Journal of Advances in Medical and Pharmaceutical Sciences. 2016; 11(2):1-10

17. Kaumar S, Jain V. Midwifery and gynecological nursing.India:CBS Publishers and Distributors pvt Ltd; 2019. 214.

18. Prathima P. Compare knowledge on self-care management of pregnancy induced hypertension between prim gravida and multigravida. Journal of Health Science. 2014; 4(3):61.

19. Shahid A, Mujawar A,Vinayak W.Patil socio-economic characteristics and pregnancy induced hypertension in the women of Western Region of India. International Journal of Medical Science. 2012;3(1):224-269.

20. Parmer M, Solanki H, Goasalia V. Study of risk Factors of perinatal death in pregnancy induced hypertension. National Journal of Community Medicine, 2012;3(4):705.

21. Martins M, MonticelliM , Bruggemann OM, Costa R. The production of knowledge regarding gestational hypertension in the
StrictoSensu graduate nursing studies inBrazil.2012;46(4):802-808.

22. El-Moselhy E, Khalifa H, Amer S, Mohamed K, Abdel-Aal H. Risk factors and impacts of pre-eclampsia: An epidemiological study among pregnant mothers in Cairo,Egypt. Journal of American Science. 2011;7(5):311-323.

23. El-Shair A.Gestational diabetes in united nation relief and working agency health clinics in Gaza Strip: Impact of educational program. Published Phd Thesis ,Cairo University, Faculty of Nursing, 2012:1-20

24. Maputle S,Khoza L, Lebese $\mathbf{R}$. Knowledge towards pregnancy induced hypertension among pregnant women. Journal Human Ecolology. $2015 ; 51(1,2): 47-54$.

25. Salim T, Kuriakose A. Knowledge of gestational hypertension and its selfcare measures among Primigravidwomen. Journal of Medical Science and Clinical Research. 2017;5(1):15328-35.

\section{Joseph J, Nayak S, Fernandes $\mathbf{P}$,} Suvarna V. Effectiveness of antenatal care package on knowledge of pregnancy induced hypertension for 
antenatal mothers in selected hospitals of Mangalore. Nitte University Journal of Health Science. 2013; 3(1):8-10.

27. Jayasutha J, Ismail AM, Senthamarai R, Visoriya SK. Assessment of impact of pregnancyinduce hypertension and patient counseling on pregnancy outcome. Research Article. 2013;1(1):86-89.

28. Kolluru V, RamyaY, Kaul R.Maternal and perinatal outcome associated with pregnancy induced hypertension. International Journal of Reproduction, Contraception, Obstetrics and Gynecology. 2016;5 (10):3367-71.

29. Parmar MR, Vaja P. Effect of pregnancy induced hypertension on maternal and perinatal outcome at Tertiary care center. International Journal of Reproduction, Contraception, Obstetrics and Gynecology. 2017;6(10):4661-65.

30. Kilembe FD, Stray-Pedersen B, Hussain A. Hypertensive disorders of pregnancy: Prevalence, maternal complications and perinatal outcomes at Lilongwe Central Hospital, Malawi. Published Master Thesis, Norway, University of Oslo, Faculty of Medicine, 2004:1-65. Available at https://www.duo.uio.no/bitstream/han
dle/10852/30097/FranklinxDavidxKile mbe.pdf? sequence $=2 \&$ is Allowed $=y$

31. Abdelati IH, Shehata S, Ibrahim SS, Farrag JM. Impact of an educational program about pregnancy induced hypertension for maternity nurses on their performance and pregnancy outcomes for mothers and neonates. Journal of Nursing and Health Science. 2016;5(5):88-99.

32. Hassan M, Begum M, Haque SMZ, Jahan N, Nazma BH, Mannan, et al. Immediate outcome of neonates with maternal hypertensive disorders of pregnancy at neonatal intensive care unit. Northern International Medical College Journal. 2015;6 (2):57-60. 